\title{
Bérrel való elégedettségi tényező egy elégedettségi vizsgálat tükrében
}

\author{
RÁCZ ANITA ${ }^{1}$
}

\begin{abstract}
ABSZTRAKT
Jelen tanulmányban egy empirikus kutatás ${ }^{2}$ keretében született vizsgálati eredmények közlésére kerül sor, melynek során láthatóvá válik a dolgozók bérrel kapcsolatos elégedettségi szintje. A 2019-ben 4 államigazgatási szerv körében lefolytatott empirikus kutatás keretében végzett online kérdőíves vizsgálat azon része kerül bemutatásra, amely a munkahelyi bérrendszer versenyképessége, a bér és a teljesítmény viszonya, valamint a bérrel és az egyéb juttatásokkal való elégedettség tekintetében adott válaszok eredményeit összesíti.

KULCSSZAVAK: közigazgatás, kormánytisztviselő, illetményrendszer, versenyképesség, elégedettség, Kit.
\end{abstract}

\section{ABSTRACT \\ Factor of wage satisfaction in the light of a satisfaction survey}

Present study reports about the survey results of an empirical research reflecting the wage satisfaction level of employees. The part of the empirical research done in 4 different administration bodies in 2019 with the help of an online questionnaire survey is presented, in which results are summarized concerning responses to competitiveness of the wage system, relation of wage and performance, and the satisfaction with wage and further allowances.

KEYWORDS: civil service, civil servant, payment system, competitiveness, satisfaction, Kit.

\section{Bevezetés}

A közigazgatásban - tekintettel a terület sajátosságára és speciális funkcióira - eltérő állami bérpolitika érvényesül a közszférán belüli más bérrendszerekhez képest. Annak ellenére, hogy a közigazgatás foglalkoztatási szabályozása az 1992. évi Ktv.-

\footnotetext{
${ }^{1}$ Nemzeti Közszolgálati Egyetem, Közigazgatás-tudományi Doktori Iskola, ariam.racz@gmail.com

${ }^{2}$ Rácz Anita Mária: Motivációs tényezők a közszféra személyi állományának foglalkoztatásában. Különös tekintettel a Kttv. és a Kit. jogszabályokban foglaltakra, a közigazgatás államigazgatási szervei vonatkozásában című értekezéstervezetben részletezett - a Nemzeti Közszolgálati Egyetem Közigazgatás-tudományi Doktori Iskola doktori képzése keretében - lefolytatott empirikus kutatásra 2019-ben került sor a közszolgálati motivációs tényezők felmérését vizsgálva.
} 


\section{TANULMÁNY}

hez képest jelentős módosításokon ment keresztül, a rendszer lényege mégis sokáig nem változott, legfeljebb helyi, illetve intézményi szinten volt lehetőség a bér bizonyos mértékű elmozdulására (Kiss 2005).

A hazai közigazgatási foglalkoztatási rendszerre 1992-től hosszú időn át a jogviszonyban töltött idő és az iskolai végzettségen alapuló besorolási rendszer volt a jellemző. Míg a versenyszférában alkalmazott Mt. és erre épülő humánerőforrásmenedzsment (kollektív szerződés és karriertervezés rendszere) nagyobb rugalmasságot biztosító rendszer, addig a közigazgatás foglalkoztatási rendszere inkább merev, kötött és az egyéni képességeket, motivációt igen ritkán értékelő, premizáló rendszerként volt jellemezhető, amely mérsékelten adott lehetőséget a teljesítmény alapú differenciálásra. Tervszerű előmeneteli rendszer, amely kiszámítható, lassú bérnövekedést biztosít, azonban az egyéni képességeket, kiemelkedő teljesítményt nem tudja megfelelően értékelni és honorálni, a személyes motivációt nem ösztönzi. A rendszer ez alapján alapvetően demotiváló és nehezíti a közigazgatásban a jó szakemberek megszerzését, valamint megtartását. A kormányzat e negatív hatást felismerve kidolgozta a 2011-ben indult, majd 2012-ben továbbfejlesztett Magyary Zoltán Közigazgatás-fejlesztési Programot (Magyary Program 11.0 és 12.0), amely az erős állam megteremtésének egyik alapjaként a közszolgálati személyzeti politika fejlesztését, stratégiai alapokra helyezését, valamint a vonzó közszolgálati életpálya megteremtését tűzte ki célul. Alapvető elhatározása a magyar közszolgálati rendszer stratégiai megújítása volt. Többek között ennek eredményeként került bevezetésre 2019. január 1-jei hatállyal a kormányzati igazgatásról szóló 2018. évi CXXV. törvény (a továbbiakban: Kit.), mint új foglalkoztatási törvény, amely alapjaiban és több lényeges ponton szakított a korábbi hagyományos szabályozással, ami legnagyobb részt a besorolási és illetményrendszert érintette.

A közigazgatásban a foglalkoztatásra vonatkozó valamennyi szabályozás célja a szervezetrendszer hatékony müködésének megteremtése, amely magában hordozza a közigazgatásban dolgozók motiválását és megbecsülését is, hiszen ezek nélkül nem várható el a magas teljesítmény. A Kit. megalkotásával a közszolgálatban dolgozók motivációs eszközei tekintetében egy alapjaiban új szabályozás született meg, melyre példa az új illetménytábla, valamint juttatási elemek bevezetése. Az új illetményszabályozás lényege, hogy a béralku lehetősége megjelenik, bár korlátozott mértékben, de a munkáltatónak nagyobb mozgásteret ad a korábbiakhoz képest, ami jelentős teljesítménynövelő, motivációs eszközként funkcionál.

A Kit.-et megelőzően a közigazgatásban dolgozók illetményét kötött előmeneteli rendszer alapján határozták meg. Az előmeneteli rendszer jellemzője volt, hogy a képzettségi szint (iskolai végzettség) és a jogviszonyban eltöltött idő alapján történt a besorolás. Tekintettel arra, hogy az illetmény mértékét a jogviszonyban töltött idő hossza befolyásolta, így általánosságban elmondható, hogy minél idősebb volt valaki, annál többet keresett. Természetesen ettől a főszabálytól eltérést jelenthetett, ha 


\section{TANULMÁNY}

a közszolgálatban dolgozót illetménypótlék (pl. idegennyelvtudási pótlék), vagy a dolgozó kiváló teljesítménye alapján a munkáltató által megállapított alapilletménytől való eltérítésre volt jogosult. Illetve az sem volt mindegy, hogy a közigazgatás központi, területi vagy helyi szervénél töltötte be az adott munkakörét, mivel az illetménykiegészítés mértéke szervenként ennek megfelelően különbözött. E rendszerben előfordulhatott, hogy a NAV-nál Budapesten dolgozó kollégák bére 20\%-kal eltérhetett egymástól annak függvényében, hogy a központi szervnél vagy a területi szervnél látta el feladatait. Ezen szabályozás szerint a jogviszonyban töltött idő növekedésével lépcsőzetesen meghatározott magasabb szorzót alkalmaztak, ezzel garantálták a tisztségviselők illetményének növekedését.

Ezen kötött illetményrendszeren lazított a Kit. szabályozása, amelynek eredményeként a központilag meghatározott szorzószámmal történő illetményszámítást felváltotta egy olyan besorolási rendszer, amely már egy minimum és maximum illetményösszeget határoz meg, mely sávon belül a munkáltató dönti el az illetmény mértékét. Így a munkáltató - az adott közigazgatási szerv rendelkezésére álló költségvetési forrás mértékéig, annak terhére - állapíthatja meg az illetményt. A jövedelemkereten belüli összeget a munkáltató saját hatáskörében, vezetői javaslat alapján hozza meg.

\section{Sávos, álláshely alapú illetményrendszer a Kit. szabályozásában}

A Kit. hatályba lépésével, a korábbiakban a közigazgatásban nem használt, új bérrendszer került bevezetésre. A kötött rendszert felváltotta a sávos, álláshely alapú bérrendszerrel, melynek keretében az illetménymegállapításnál a minimum és maximum összeget meghatározó sávon belül lehetőséget kap a munkáltató a személyes kompetenciák, teljesítmények, érdemek elismerésére. Az illetmények egyszerűbb módon kalkulálhatóak, nem szükséges az illetmény kiszámításához a korábbi jogviszonyok igazolása sem, a munkáltatói jogkör gyakorlója által a törvény mellékletében található, illetménysávon belül, szubjektív döntéssel kerül az illetmény megállapításra. Ez jóval egyszerűbb módszer a bér meghatározására, mint a korábban alkalmazott illetményalapból, alapilletményből, illetménykiegészítésből és pótlékokból kalkulált, objektíve meghatározott bér. A jogalkotó szándéka az új szabályozási rendszerrel a kormánytisztviselők számára az ellátott feladatokkal és kapcsolódó felelősséggel arányban álló illetménymegállapítás biztosítása.

Az illetmény megállapítása során a munkáltatói jogkör gyakorlójának lehetősége van mérlegelni, hogy mekkora illetményt kíván megadni a kormánytisztviselőnek az adott álláshelyhez tartozó illetménysávon belül. Természetesen ennek meghatározása több tényezőtől függ, hiszen mérlegelheti a kormánytisztviselő iskolai végzettségét, szakmai tapasztalatát, nyelvtudását, esetlegesen a korábbi munkahelyén biztosított bér nagyságát és ezek alapján határozza meg az adott illetménysáv alsó, 


\section{TANULMÁNY}

illetve felső határa között adható, konkrét illetményt. ${ }^{3}$ Béralkut tesz lehetővé az új rendszer bizonyos korlátok között, illetve a törvény garanciális szabályként rögzíti, hogy az illetmény összegének legalább a - Kormány által rendeletben megállapított - garantált bérminimum összegét el kell érnie.

\section{Az empirikus kutatás}

A közszolgálati motivációs tényezőket vizsgáló empirikus kutatás keretében végzett online kérdőíves felmérést ${ }^{4}$ négy államigazgatási szervnél folytattam le, melyből három szerv (fóvárosi és) megyei kormányhivatal, egy autonóm államigazgatási szerv volt. A kutatás az adott államigazgatási szerveknél foglalkoztatott személyi állományra terjedt ki, mind vezetői, mind ügyintézői körben. A kérdőíves felmérés keretében a kutatásban részt vett személyi állomány részére online, anonim módon történő kitöltés lehetőségét biztosítottam. A kutatás eredményétől - az empirikus vizsgálat lefolytatását megelőzően - azt vártam, hogy a kutatásban részt vettek válaszaira alapozva saját képet kapjak a közigazgatás motivációs rendszeréről alkotott nézetekről, véleményekről.

A kutatásba bevont államigazgatási szervek esetében biztosítottam a teljes körü anonimitás lehetőségét, így ennek eredményeként az online kérdőíves megkérdezés keretében adott válaszok elemzése során az egységességet szem előtt tartva egyöntetűen a közigazgatási szerv - anonimitását megőrizve - megnevezése nélkül kerülnek az adatok, kimutatások feltüntetésre. A kérdőíves megkérdezés lefolytatására, a kérdések megválaszolására az adott szerv - vezetői döntéstől függően - 1-2 hetet biztosítottak.

A kérdőív legnagyobb részét tették ki, valamint a kérdőív vázát alkották a motivációs tényezőkre és ösztönzőrendszerre vonatkozó kérdések, melyből jelen a közigazgatás bérrendszerére vonatkozó négy vizsgálati kérdésre adott válaszok eredményei, megállapításai kerülnek bemutatásra. A kérdések kapcsán a válaszadók a személyes megítélésüket, a kérdések értékelését egy 0-tól 5-ig terjedő, 6 fokozatú Likert-skálán ${ }^{5}$

\footnotetext{
${ }^{3}$ A kormánytisztviselő megállapított illetménye az adott naptári évben a teljesítményértékelése alapján módosítható. A teljesítményértékelés alapján a kormánytisztviselő illetménye az adott besorolási kategóriához tartozó összeghatáron belül legfeljebb 20\%-kal csökkenthető, illetve legfeljebb 30\%-kal növelhető.

${ }^{4}$ A kérdőíves vizsgálat a tudományos adatgyűjtés egyik speciális és gyakran alkalmazott módszere, melynek során kérdőív segítségével kerül feltérképezésre a megkérdezettek véleménye a kutatás tárgyáról (Hornyacsek Júlia [2014]: A tudományos kutatás elmélete és módszertana. Szakkönyv tudományos munkát végzők és doktori tanulmányokat folytatók számára. Nemzeti Közszolgálati Egyetem, Budapest, ISBN 978-615-5491-36-8, 91. old.)

${ }^{5}$ Rensis Likert amerikai pszichológus és szociológus által a doktori értekezéséhez 1932-ben kifejlesztett Likert-skála módszerének lényege, hogy különböző állításokat két szélsőséges végpont között kialakított skálán értékelnek. „Mind a két esetben az egyik végpont abszolút ellenkezést, míg a másik abszolút egyetértést, azonosulást testesít meg, amelyek között a válaszadó elhelyezheti véleményét az adott állítással kapcsolatban." (Zerényi 2016: 470)
} 


\section{TANULMÁNY}

végezték el. 0 pontot adtak, ha az állítás egyáltalán nem jellemző a szervre, fennálló helyzetre, 5 pont pedig a maximálisan jellemző minőséget jelöli.

\section{A kérdőíves vizsgálatban résztvevők köre}

A kutatás kérdőíves megkérdezésében összesen 1249 fő vett részt, a Szerv 1. részéről, 404 fő (32,35\%), a Szerv 2. állományából 513 fő (41\%), a Szerv 3. részéről 305 fő $(24,42 \%)$ és a Szerv 4. foglalkoztatottjaiból 27 fő $(2,16 \%)$.

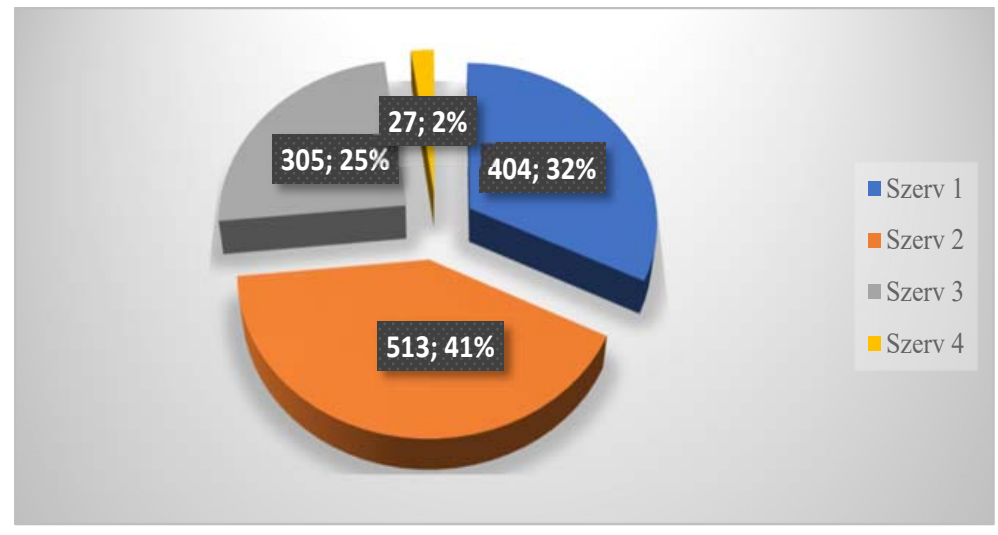

1. ábra. Az online kérdőíves vizsgálatban résztvevők köre Forrás: Saját szerkesztés

A kutatásban részt vettek az adott államigazgatási szerveknél foglalkoztatott személyi állomány vezetői és ügyintézői is. Az összes kérdőívet kitöltők közül 16 fő (1,28\%) felsővezető, 139 fő $(11,13 \%)$ középvezető, 1084 fő $(86,79 \%)$ szellemi alkalmazott, 10 fö $(0,8 \%)$ fizikai alkalmazott volt.

\section{A munkahelyi bérrendszer versenyképessége a magánszférához képest}

A jó javadalmazási politika egy olyan bérrendszert alkalmaz, ami a munkaerőpiacon is versenyképes jövedelempolitikát követ, összhangban van a végzett munkával, valamint igazságos és méltányos a szervezeten belüli munkakörök szempontjából is. A szervezet bérpolitikája az egyéb motivációs tényezők mellett fontos eszköze a dolgozók teljesítménynövelésének. A fizetés számos előnnyel rendelkezik a többi motivációs tényezőhöz képest, hiszen rendszeres, értéket jelent és folyamatosnak tekinthető mindenkinél a pénz iránti szükséglet megléte. Alfred Marshall (Marshall 1961) kialakította a bérhatékonyság fogalmát: az alacsony bér arra sarkallja a munkavállalót, hogy munkaerejét elvonja a munkáltatótól, és lehetőleg alternatív bevételi 


\section{TANULMÁNY}

források után nézzen, de legalábbis igyekezzék idejét, energiáját a munkahelyen kívüli élet megpróbáltatásaira fenntartani. Az alacsony bér tehát csak látszólag hatékony, valójában lerontja a termelékenységet. A bér növelése ugyanakkor nem korlátlanul javítja a termelékenységet, hiszen adott szint fölött már nagyobb szubjektív hasznossággal jár a megkeresett jövedelem elköltése, mint a jövedelem további növelése.

Említést érdemel a közszféra és a magánszféra közötti karrierválasztási és mobilitási különbségeket feltáró 2013 júniusában lefolytatott empirikus vizsgálat, mely szerint a közszférában való munkavállalás - a megkérdezettek véleménye alapján „romló, csökkenő presztizsű, a hátrányos megítélést elsősorban az utóbbi évek negatív anyagi mérlege, a terhek megnövekedése és a megbecsülés hiánya adja” (Gellén 2013).

A kérdöív vizsgálati kérdése: Ön szerint mennyire versenyképes a munkahelyének bérrendszere a magánszférához képest?

Az 1249 főből a válaszadók többsége a munkahelyének bérrendszerét kevésbé tartja versenyképesnek a magánszférához képest. Ezt mutatja, hogy 368 fő (29,46\%) egyáltalán nem tartja a bérrendszert versenyképesnek a magánszféra viszonyrendszerében, 261 fő (20,9\%) alacsony szintűre, 1-esre értékelte a bérrendszer versenyképességét. 272 fő $(21,78 \%)$ adott 2-es, 239 fö $(19,14 \%)$ adott 3-as értéket. A magasabb pontértékeket viszonylag kevesen választották, 93 fő $(7,45 \%)$ értékelte 4-esre és csupán 16 fő (1,28\%) értékelte 5-ösre a munkahelye bérrendszerének versenyképességét a magánszférához képest.

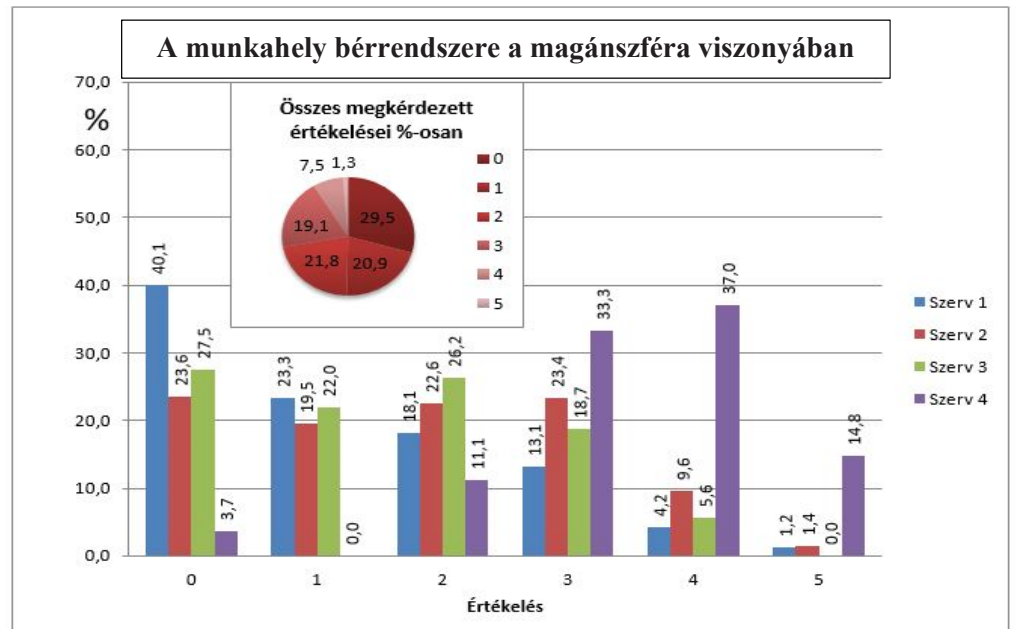

2. ábra. A kérdőíves felmérésben részt vevők véleménye a munkahely bérrendszeréről a magánszféra viszonyában \%-os eloszlásban

Forrás: Saját szerkesztés 


\section{TANULMÁNY}

\section{A munkavégzés során nyújtott teljesítmény fizetéssel való arányossága}

Megállapítható, hogy amennyiben egy munkavállaló ugyanazt a fizetést kapja meg kiemelkedő teljesítmény nyújtása mellett, mint egy másik ugyanolyan munkakörben dolgozó munkatársa alacsony teljesítmény mellett, a kiemelkedő teljesítményt nyújtó munkavállalóra ez demotiváló hatással van. Ezért is fontos, hogy a munkáltató teljesítménnyel arányos bérpolitikát kövessen. A munkavállalók teljesítményének értékelésére egyéni mérés szerint, a szervezet céljaihoz mérten kerül sor.

A kérdő́iv vizsgálati kérdése: Mennyire gondolja azt, hogy a munkája során nyújtott teljesítménye arányos a fizetésével?

A megkérdezettek véleménye a munkájuk során nyújtott teljesítmény és a fizetés ${ }^{6}$ arányosságáról vegyes képet mutat. 196 fő $(15,69 \%)$ adott legalacsonyabb értéket, így ennyien gondolják azt, hogy az általuk nyújtott teljesítmény egyáltalán nincsen összhangban a megkapott bérrel (elégedetlenség). 218 fő (17,45\%) adott 1-es, 243 fő $(19,46 \%)$ adott 2 -es értéket. A válaszadók nagy része választotta a 3-as értéket (317 fő, 25,38\%) és a 4-es értéket (227 fö, 18,17\%). Ezzel szemben kevésnek mondható azoknak a száma (48 fó, 3,84\%), akik úgy gondolják, hogy a munkájuk során nyújtott teljesítmény és a kapott fizetés egymással arányban áll.



3. ábra. A kérdőíves felmérésben részt vevők véleménye a munkájuk során nyújtott teljesítmény és a fizetés arányosságáról \%-os eloszlásban

Forrás: Saját szerkesztés

${ }^{6}$ 2020. januárban a bruttó átlagkereset 375200 forint, a nettó átlagkereset 249500 forint volt. Ehhez képest 2020. januárban a közszféra átlagkeresete bruttó 341500 forint, nettó 227100 forint volt, ami jóval alulmaradt a vállalkozások átlagkeresetéhez képest (bruttó 390600 forint, nettó 259800 forint). (Az átlagkeresetek összegében a koronavírus-járvány hatása a vizsgált időszakban még nem jelentkezett.) [KSH 2020. január havi bruttó átlagbér. KSH Gyorstájékoztató (2020): Keresetek, 2020. Közzététel: 2020. március 31.] https://www.ksh.hu/docs/hun/xftp/gyor/ker/ker2001.html 


\section{TANULMÁNY}

\section{Bérrel való elégedettség}

A bér ${ }^{7}$ lényegében a munkáért járó ellentételezés. Világunkban a pénz fontossága és betöltött szerepe nem kérdőjelezhető meg, ellenben megállapítható, hogy a pénz értéke és annak motivációs ereje nagyban függ a dolgozó értékrendjétől, a motivációs számításától, valamint a pénz felhasználhatóságától. A pénz megerősítő jellegét tekintve pedig, amennyiben a munkavállalók a jutalmakat szabályos időközönként kapják, annak csekély motiváló hatása van, ezért a havi szinten kapott fizetés inkább „munkakörülményként” értelmezhető. Természetesen ez alól kivételt képeznek a teljesítményarányos javadalmazási rendszerek, melyek motiváló hatással bírnak. (Farkas - Balogh - Rideg 2015)

A közigazgatásban jelenlévő bérrendszerre vonatkozóan - felölelve a fizetéssel való elégedettséget - az illetmény mint motivációs tényező, az egyik legfontosabb szervezeti erőforrás meghatározó tényező a szervezet működési irányában (Gellén 2015).

\section{A kérdőív vizsgálati kérdése: Mennyire elégedett a bérével?}

A megkérdezettek közül 188 fő (15,05\%) állította azt, hogy egyáltalán nem elégedett a bérével. Kevésbé mutatnak elégedettséget az 1-es értéket adók (203 fó, 16,25\%), valamint a 2-es értéket adók (242 fô, 19,38\%). A válaszadók nagy része választotta a 3-as értéket (317 fó, 25,38\%). Második legnagyobb részt a 4-es értéket választottak teszik ki (260 fö, 20,82\%). Kevésnek mondható a bérükkel maximálisan elégedettek száma, mivel az 5-ös értéket csupán 39 fő (3,12\%) választotta.

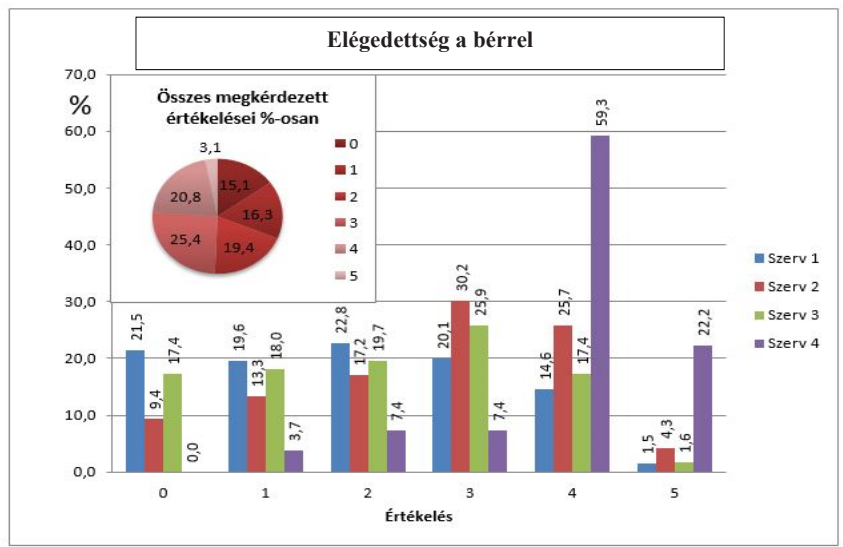

4. ábra. A kérdőíves felmérésben részt vevők elégedettsége a bérrel \%-os eloszlásban Forrás: Saját szerkesztés

\footnotetext{
${ }^{7}$ Magyarországon 2019. januártól szeptemberig terjedő időszakban a teljes munkaidőben alkalmazásban állók nemzetgazdasági szintű havi bruttó átlagkeresete 359900 Ft volt, ami 10,8\%-kal haladta meg az egy évvel korábbi átlagkereseti adatokat. Központi Statisztikai Hivatal (2019): Magyarország, 2019. I-III. negyedév. http://www.ksh.hu/docs/hun/xftp/idoszaki/mone/mo1909.pdf
} 


\section{TANULMÁNY}

\section{Az egyéb juttatásokkal való elégedettség}

Az egyéb juttatások közé több juttatási elem is tartozik. Kiemelt szerepet tölt be a cafetéria-juttatás, ami béren kívüli elemként egyéb juttatásnak minősül. Ide tartozik többek között - az étkezési hozzájárulás, ruhapénz, telefonszámla-térítés, lakhatási támogatás, tanulmányi támogatás, szociális hozzájárulás, egészségügyi szűrővizsgálatok stb. A béren kívüli juttatási elemek ritkán hatnak közvetlenül a dolgozók munkahelyi teljesítményére, de az ösztönzési rendszert vonzóbbá téve, mindenképpen hozzájárulnak a munkáltató iránti elköteleződéshez és támogatják a szervezethez való pozitív hozzáállást (Krauss - Petró 2014).

\section{A kérdőív vizsgálati kérdése: Mennyire elégedett az egyéb juttatásokkal?}

A kutatás során a válaszadók többsége a teljes mértékű elégedetlenségét fejezte ki az egyéb juttatásokkal összefüggésben. Bizonyítja ezt az, hogy az 1249 fő megkérdezett közül 530 fő $(42,43 \%)$ választotta a 0 értéket az egyéb juttatásokkal kapcsolatos elégedettség terén, 222 fő $(17,77 \%)$ pedig az ugyancsak alacsony szintű 1-es értéket adott. 194 fő (15,53\%) értékelte az egyéb juttatásokkal kapcsolatos elégedettségét 2-es értékűre, 3-as minősítést pedig 159 fő (12,73\%) adott. 103 fő (8,25\%) jelezte a válaszában viszonylag elégedettségét a 4-es érték megadásával. A válaszadók csupán elenyésző részét teszik ki azoknak a száma, akik az egyéb juttatásokkal kapcsolatosan maximális elégedettséget éreznek (41 fô, 3,28\%). Jelen tanulmányban részletesen közölt egyéb juttatási szabályok a jelek szerint - terjedelmük és kidolgozottságuk ellenére - inkább irritálják, semmint ösztönzik a válaszadókat.

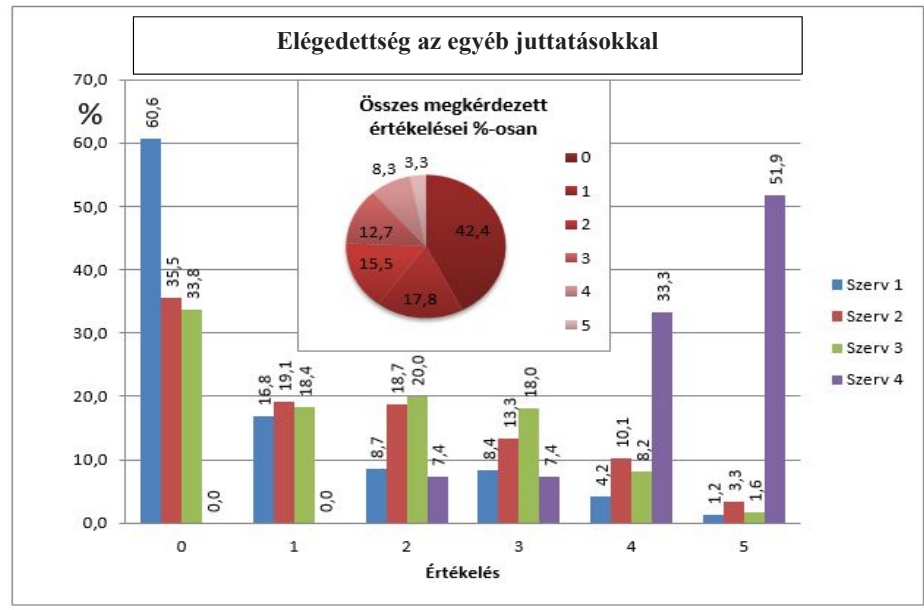

5. ábra. A kérdőíves felmérésben részt vevők elégedettsége az egyéb juttatásokkal \%-os eloszlásban

Forrás: Saját szerkesztés 


\section{TANULMÁNY}

\section{Összegzés}

Jelen tanulmányban részletezett bérrel kapcsolatos elégedettségi mutatók bemutatására egy 2019-ben lefolytatott - közszolgálati motivációs tényezők felmérését vizsgáló - empirikus kutatás során feltett kérdésekre adott válaszok alapján került sor. A fent részletezett kutatási eredményeket mindenképpen érdemesnek tartom összehasonlítani az ugyanezen témában 2014-ben a „Jó Állam” koncepcióval összefüggésben végzett kutatás megállapításaival.

A „Jó Állam” koncepcióval kapcsolatos kutatás ${ }^{8}$ a bizalom, az együttműködés és a hatékonyság közigazgatással kapcsolatos összefüggéseit mérte vezetői, kormánytisztviselői szinten, valamint a lakosság és az egyetemi hallgatók körében. A vizsgálati kutatás során 40 db mélyinterjú készült vezetőkkel, 11004 fő kormánytisztviselő részéről online kérdőív megválaszolására került sor, a lakosság körében reprezentatív kérdőíves felmérés történt, valamint az egyetemi hallgatók körében is kérdőíves megkérdezés zajlott.

A vizsgálati kutatási kérdések a Magyary Programban meghirdetett „Jó Állam” koncepciója köré szerveződtek. A 2014-ben lefolytatott kutatás többek között kitért a vezetők által hatékonynak ítélt motivációs eszközökre, mely jelen tanulmány témája szempontjából is relevanciával bír. A vezetői mélyinterjúkat 2014. februárban és márciusban folytatták le, melynek során összesen 40 fővel végeztek átlagosan 1 óra terjedelmű interjút. A kutatás mélyinterjúba bevont vezetői minisztériumok, kormányzati hivatalok megyei és járási kormányhivatalok vezető és középvezető munkatársai voltak. Az érintett vezetők többségében helyettes államtitkárok és osztályvezetők voltak, többnyire jogi-igazgatási, HR és ágazati szakmai vezetői körből. A kutatás megállapítása, hogy a mélyinterjúba bevont vezetők által hatékonynak tekintett motivációs eszközök körében - a vezetett szervezeti egységtől és ágazattól függetlenül - az anyagi kompenzáció minősült a legjobb motivációs tényezőnek. Ezzel összefüggésben megállapítást nyert, hogy a közigazgatásban dolgozók bérjuttatása a versenyszférához hasonlítva - kevésbé versenyképes. Továbbá a kutatás keretében felmért, havi fizetéssel való elégedettség szempontjából a kilátástalanság volt a döntő tényező (Gellén 2015). „A hivatali kompenzáció versenyképességének hiánya a gazdaság kis mértékű gyorsulása, ezzel együtt a piaci körülmények között elérhető juttatások relatív emelkedése következtében 2013-tól már érezhetően befolyásolta az állásokra pályázók bérelvárásait a megkérdezett vezetők szerint." (Gellén 2015)

Az eltérő időpontokban és módszerekkel végzett kutatások mindegyike arra az eredményre jutott, hogy a bér kiemelkedő jelentőségű a motivációs tényezők közül. Némi különbség érzékelhető a közszféra béreinek megítélése tekintetében, noha

${ }^{8}$ Az ÁROP 1.1.26-2013-2013-0001 keretében elvégzett kutatás a „Jó Állam” koncepcióval kapcsolatos percepciókat méri..." (Gellén M. [2015]: Közigazgatás: Reform után, átalakítás közben. A 2010-2014-es időszak közigazgatási reformja az érintettek véleménye alapján. Patrocinium Kiadó, Budapest, 35. old.) 


\section{TANULMÁNY}

2019-ben sem voltak maradéktalanul elégedettek a bérekkel a közigazgatásban dolgozók, azonban kilátástalanság nem volt tapasztalható, amely helyzet egyik lehetséges okaként a Kit. bevezetésével eszközölt bérrendezés is megemlíthető.

Összefoglalva tehát elmondható, hogy a közigazgatás illetményrendszerében, a Kit. által eszközölt módosítások szükségességét és időszerűségét is alátámasztották a közigazgatáson belüli humánerőforrás-gazdálkodás hatékonyságát vizsgáló mérési eredmények.

\section{Irodalom}

Farkas F. - Balogh G. - Rideg A. (2015): Menedzsment alapvetések és funkciók. Pécsi Tudományegyetem Közgazdaságtudományi Kar, Pécs

Kiss Gy. (2005): Munkajog. Budapest, Osiris Kiadó

Krauss G. - Petró Cs. (2014): A közszolgálat béren kívüli juttatási rendszerének aktuális kérdései. Pro Bublico Bono - Magyar Közigazgatás 2014 (4): 45-46.

Gellén M. (2013): A közszféra és a magánszféra viszonya az egyéni karrierutak tervezésében. Pro Bublico Bono - Magyar Közigazgatás, (4): 36-47.

Gellén M. (2015): Közigazgatás: Reform után, átalakítás közben. A 2010-2014-es időszak közigazgatási reformja az érintettek véleménye alapján. Patrocinium Kiadó, Budapest

Hornyacsek Júlia (2014): A tudományos kutatás elmélete és módszertana. Szakkönyv tudományos munkát végzők és doktori tanulmányokat folytatók számára. Nemzeti Közszolgálati Egyetem, Budapest

Kádár K. (2019): Hatékony közigazgatás. In: Jó állam jelentés 2019. NKE - Kutatásmódszertani és Mérésügyi Iroda. 157. old.

https://joallamjelentes.uni-nke.hu/kiadvanyok/jo-allam-jelentes-2019-elsovaltozat/ (Letöltve: 2020. 05. 06.)

Központi Statisztikai Hivatal (2019): Magyarország, 2019. I-III. negyedév http://www.ksh.hu/docs/hun/xftp/idoszaki/mone/mo1909.pdf (Letöltve: 2020. 06. 26.)

[KSH 2020. január havi bruttó átlagbér. KSH Gyorstájékoztató (2020): Keresetek, 2020. Közzététel: 2020. március 31.]

https://www.ksh.hu/docs/hun/xftp/gyor/ker/ker2001.html (Letöltve: 2020. 10. 18.

Marshall, A. (1961): Principles of Economics. An Introductory Volume. 8th edition. English Language Book Society \& Macmillan Co. London. 
www. metszetek.unideb.hu



\section{TANULMÁNY}

http://krishikosh.egranth.ac.in/bitstream/1/77892/1/PRINCIPLES\%200F\% 20ECONOMICS.pdf. (Letöltve: 2020. 10. 07.)

Zerényi K. (2016): A Likert-skála adta lehetőségek és korlátok. Opus et Educatio 3. évf. 4. szám 470. 